J. Product. \& Dev. ,11 (1): 123- 135(2006)

\title{
EFFECT OF CHEMICAL, ORGANIC FERTILIZERS AND ACTIVE DRY YEAST ON SALVIA OFFICINALIS, L. PLANTS. \\ I. FFECT ON GROWTH AND YIELD.
}

A. S. EL-Leithy*; M. M.M. Hussein *; E. A. E. EL-Ghadban** and Esraa S. M. Abd EL-Latif **

*Ornamental Horticulture Department, Faculty of Agriculture, Cairo University, , Cairo, Egypt.

** Medicinal and Aromatic Plants Research Department, Horticulture Research Institute, Agricultural Research Center, Dokki , Cairo, Egypt.

\section{ABSTRACT}

The present study was conducted during the two successive seasons of 2003/2004 and 2004/2005 at the Farm of Ornamental Horticulture Department, Faculty of Agriculture, Cairo University and Medicinal and Aromatic Plants Department, Horticulture Research Institute, Agricultural Research Center, Dokki, Giza to investigate the effect of chemical fertilizers (NPK), organic manure (poultry manure) and spraying active dry yeast on sage (Salvia officinalis) plants .The results showed that, NPK fertilizer [300 $\mathrm{kg}$ ammonium sulphate $(20.6 \% \mathrm{~N}), 200 \mathrm{~kg}$ calcium superphosphate $(15.5 \%$ $\left.\mathrm{P}_{2} \mathrm{O}_{5}\right)$ and $100 \mathrm{~kg}$ potassium sulphate $\left(48 \% \mathrm{~K}_{2} \mathrm{O}\right) /$ fad./ season ] significantly increased plant height, number of branches/ plant, leaf area, leaves, stems and herb fresh and dry weights/ plant compared to the control, in most cases.

In general, poultry manure (PM) fertilizer at 10 and $20 \mathrm{~m}^{3} / \mathrm{fad} / \mathrm{season}$ significantly increased number of branches/ plant, leaf area, fresh and dry weights of leaves, stems and herb / plant compared to the control. Also, plant height was significantly increased as a result of using PM at $20 \mathrm{~m}^{3} / \mathrm{fad} . \mathrm{PM}$ at $20 \mathrm{~m}^{3} / \mathrm{fad}$ was more effective than $10 \mathrm{~m}^{3} / \mathrm{fad} /$ season.

Spraying active dry yeast alone at $5 \mathrm{~g} / \mathrm{L}$ significantly increased plant height, leaf area, fresh and dry weights of leaves and herb, and dry weight of stems in the first cut of both seasons. It also significantly increased fresh weight of stems in the first season in both cuts .

Generally, interaction between PM fertilizer at 10 or $20 \mathrm{~m}^{3} / \mathrm{fad} /$ season and spraying plants with active dry yeast at $5 \mathrm{~g} / \mathrm{L}$ significantly increased plant height, number of branches / plant, leaf area, leaves fresh and dry weights/ plant and herb fresh and dry weights / plant in both cuts of the two seasons, compared to the control. PM at $20 \mathrm{~m}^{3} /$ fad plus active dry yeast at $5 \mathrm{~g} / \mathrm{L}$ was recommended.

Keywords: Chemical, organic fertilizers, active dry yeast, salvia officinalis, yield. 


\section{INTRODUCTION}

Common sage (Salvia officinalis, L.) belonging to Family Lamiaceae. It possess carminative, antispasmodic, antiseptic, astringent, anti-oxidant, astringent ,digestive, diuretic, laxative, stomachic and antihidrotic properties (Lawless, 1992) and external use for inflammations of the mouth, tongue and throat and the mucous membranes of nose (Blumenthal et al., 2000 ).

Many researchers stated that chemical fertilization affected the growth and chemical constituents of different aromatic plants [Sakr (2001)on Mentha piperita; Mohsen (2002) on Ocimum basilicum and Abd El-Azim (2003) on Salvia officinalis].

The organic fertilizers are much more likely to increase both yield and quality, at the same time providing an alternative habitat for wildlife, and producing plants that are safe flavorsome, and chemicals free [Sakr (2001) on Mentha piperita; Mohsen (2002)on Ocimum basilicum ; Naguib (2002) on Cymbopogon flexuosus and El - Ghadban et. al., (2003 a) on Origanum majorana] .

Yeast (natural stimulator) is one of these substances which characterized by its richness in protein, vitamin B content, thiamin, riboflavin and pyridoxines. Also yeast are prolific producers of vitamins, amino acids, hormones and other growth regulating substances (Eid, 1977). Concerning chemical analysis of the active dry yeast, Ahmed et al.(1997) found that it contained $34.87 \%$ protein, $7.55 \%$ ash, 6.54\% Glycogen, $2.9 \%$ fats and $4.92 \%$ cellulose. Yeast contains tryptophan which consider a precursor of IAA (Moor,1979). Yeast also contains cytokinins thus delays the aging of leaves by the way of retardation the degradation of chlorophyll and enhancing the synthesis of protein and RNA ( Natio et al.1981 ). In this respect, many researchers stated that active dry yeast affecting growth and chemical composition of many aromatic plants [Naguib (2002) on Cymbopogon flexuosus ; El-Ghadban et. al., (2003 b) on Ricinus communis and Salman (2004) on Ocimum basilicum].

\section{MATERIALS AND METHODS}

The present study was conducted during the two successive seasons of 2003/2004 and 2004/2005 at the Farm of Ornamental Horticulture Department, Faculty of Agriculture, Cairo University and Medicinal and Aromatic Plants Department, Horticulture Research Institute, Agricultural Research Center, Dokki, Giza to investigate the effect of chemical fertilizers (NPK), organic manure (poultry manure) and biofertilization (active dry yeast) on sage plants (Salvia officinalis, L.).

Seeds of sage (Salvia officinalis, L.), local variety were secured from the private farm in Sheikh Zowaid, North Sinai and sown in nursery beds with a clay soil on $10^{\text {th }}$ November in the two seasons . The seedlings $(10-15 \mathrm{~cm}$ height) were transplanted in sandy loam soil on $25^{\text {th }}$ February. The physical and chemical analysis of soil (Table A) and chemical analysis of the organic fertilizers (Table B) were carried out according to the method described by Jackson, 1973.

The following fertilization treatments were used:

- Control (untreated plants). 
Table (A): Physical and chemical analysis of the soil used for growing sage (Salvia officinalis, L.) plants, before treatments.

\begin{tabular}{|c|c|c|c|c|c|c|c|c|c|c|c|}
\hline \multicolumn{12}{|c|}{ 1- Physical analysis } \\
\hline \multicolumn{3}{|c|}{ Clay (\%) } & \multicolumn{2}{|c|}{ Silt (\%) } & \multicolumn{3}{|c|}{ Sand (\%) } & \multicolumn{4}{|c|}{ Texture grade } \\
\hline \multicolumn{3}{|c|}{18.5} & \multicolumn{2}{|c|}{26.3} & \multicolumn{3}{|c|}{55.2} & \multicolumn{4}{|c|}{ Sandy loam } \\
\hline \multicolumn{12}{|c|}{ 2- Chemical analysis } \\
\hline \multirow[b]{2}{*}{$\sqrt{2}$} & \multirow[b]{2}{*}{ 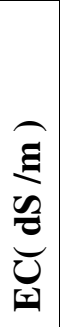 } & \multicolumn{3}{|c|}{$\begin{array}{l}\text { Total nutrients } \\
\text { content (ppm) }\end{array}$} & \multicolumn{4}{|c|}{$\begin{array}{c}\text { Soluble cations } \\
\text { Meq /L }\end{array}$} & \multicolumn{3}{|c|}{$\begin{array}{c}\text { Soluble anions } \\
\text { Meq /L }\end{array}$} \\
\hline & & $\mathbf{N}$ & $\mathbf{P}$ & $\mathbf{K}$ & Z & $\stackrel{+}{4}$ & שَ & $\sum^{+\infty}$ & $\overbrace{}^{\prime}$ & $\bar{\tau}$ & $\dot{0}$ \\
\hline$\stackrel{n}{r}$ & $\stackrel{\overbrace{}}{\stackrel{f}{+}}$ & $\stackrel{?}{\stackrel{\overbrace{}}{\sim}}$ & $\begin{array}{l}8 \\
\infty \\
\stackrel{0}{0} \\
\stackrel{0}{1}\end{array}$ & $\begin{array}{l}\stackrel{P}{P} \\
\stackrel{+}{+} \\
\text { m. }\end{array}$ & 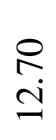 & $\frac{2}{6}$ & $\stackrel{0}{\stackrel{0}{\infty}}$ & $\stackrel{?}{\stackrel{+}{+}}$ & $\underset{8}{8}$ & $\stackrel{+}{\Xi}$ & $\stackrel{\infty}{\stackrel{\infty}{m}}$ \\
\hline
\end{tabular}

Table (B): The chemical analysis of the organic fertilizer applied to sage ( Salvia officinalis, L.) plants during 2003 / 2004 and 2004/2005 seasons.

\begin{tabular}{lcc}
\hline Organic Manure Characteristics & First season & Second season \\
\hline Weight of $\mathbf{~ m}^{\mathbf{3}}(\mathbf{k g})$ & 688.00 & 534.00 \\
Moisture content $(\%)$ & 6.90 & 9.56 \\
Organic matter (\%) & 65.69 & 83.61 \\
Organic carbon (\%) & 36.45 & 49.91 \\
Total N (\%) & 2.30 & 3.66 \\
$\mathbf{C}: \mathbf{N}$ ratio & $15.4: 1$ & $13.2: 1$ \\
$\mathbf{N H}_{3}-\mathbf{N}(\mathbf{p p m})$ & 3021.8 & 3489.90 \\
$\mathbf{N O}_{\mathbf{3}} \mathbf{N}(\mathbf{p p m})$ & 174.9 & 224.60 \\
$\mathbf{T o t a l}_{\mathbf{P}}(\boldsymbol{\%})$ & 1.19 & 0.75 \\
\hline
\end{tabular}

- Chemical fertilizer (NPK) at $300 \mathrm{~kg}$ ammonium sulphate $(20.6 \% \mathrm{~N}), 200 \mathrm{~kg}$ calcium superphosphate $\left(15.5 \% \mathrm{P}_{2} \mathrm{O}_{5}\right)$, and $100 \mathrm{~kg}$ potassium sulphate $\left(48 \% \mathrm{~K}_{2} \mathrm{O}\right) /$ fad./ season .

- Poultry manure (PM) at 10 and $20 \mathrm{~m}^{3} / \mathrm{fad} /$ season. 
- Active dry yeast at the rate of $5 \mathrm{~g} / \mathrm{L}$.

- Poultry manure (PM) at $10 \mathrm{~m}^{3} / \mathrm{fad} /$ season $+5 \mathrm{~g}$ active dry yeast $/ \mathrm{L}$.

- Poultry manure (PM) at $20 \mathrm{~m}^{3} / \mathrm{fad} /$ season $+5 \mathrm{~g}$ active dry yeast $/ \mathrm{L}$.

The NPK mixture was divided into two equal doses as a basal dressing. The first dose was applied one month after transplanting and the second one was applied after the first cut. The organic fertilizer was applied in two doses. The first dose $(2 / 3$ of the application rate) was incorporated with the soil two weeks before transplanting, and the second one was applied as a basal dressing after the first cut.

The active dry yeast at $5 \mathrm{~g} / \mathrm{L}$ was sprayed four times, the first was applied after 30 days from transplanting and the second was applied after 15 days of the first one, the third spray took place one month after the first cut and the fourth was applied after one month of the third spray .The plants were harvested twice (first week of June and first week of September) by cutting the herb at $10 \mathrm{~cm}$ above the soil surface.

The layout of the experiment was a complete randomized blocks design included seven treatments with three replicates. The experimental area was $(2 \times 2 \mathrm{~m})$ with three rows. Each replicate contained 18 plants. The following data were recorded in each cut: Plant height, leaf area (the fifth leaf from the shoot apex ), number of branches, herb fresh and dry weights / plant (g).

Data recorded on vegetative growth parameters were statistically analyzed using the Least Significant Difference (L.S.D.) test at 5\% level, as described by Snedecor and Cochran (1980).

\section{RESULTS AND DISCUSSION}

\section{Plant height :}

Data in Table (1) showed that, in both seasons, NPK treatment increased plant height significantly over the control. The increment in plant height might be attributed to the accumulation of nutrient materials and metabolic activity. These results agreed with the findings reported by El-Ghadban (1998) on Mentha viridis; and Mohsen (2002) on Ocimum basilicum as they all indicated that NPK fertilization increased plant height.

In the two seasons, data of both cuts reveal that two rates of organic fertilizer treatments used increased plant height compared with the control. In both seasons using the higher rate of PM (20 $\mathrm{m}^{3}$ /fad ) significantly increased plant height in both cuts, compared to the control. Increasing fertilizer doses gradually increased plant height. Poultry manure at the rate of $20 \mathrm{~m}^{3} / \mathrm{fad}$ was more effective than $10 \mathrm{~m}^{3} / \mathrm{fad}$ in increasing plant height. Similar results were obtained by Jacoub (1999) on Ocimum basilicum and Thymus vulgaris and Mohsen (2002) on Ocimum basilicum since they all showed that organic fertilizers increased plant height.

Regarding the use of active dry yeast at $5 \mathrm{~g} / \mathrm{L}$ alone in the first season there was no significant increase in the plant height compared to the control in the second cut, whereas in the first cut and in the second season in both cuts, active dry yeast significantly increased plant height. These results agreed with Hussain (2002) on 
Table (1 ): Effect of chemical, organic fertilizers (PM) and active dry yeast on plant height, number of branches and leaf area of sage( Salvia officinalis, L. ) plants during of 2003 / 2004 and 2004 / 2005 seasons.

\begin{tabular}{|c|c|c|c|c|c|c|}
\hline \multirow[t]{2}{*}{ Treatments } & \multicolumn{2}{|c|}{ Plant height(cm) } & \multicolumn{2}{|c|}{ No.branches/plant } & \multicolumn{2}{|c|}{ Leaf area $\left(\mathrm{cm}^{2}\right)$} \\
\hline & $\begin{array}{l}1^{\text {st }} \\
\text { cut }\end{array}$ & $\begin{array}{l}2^{\text {nd }} \\
\text { cut }\end{array}$ & $\begin{array}{l}1^{\text {st }} \\
\text { cut }\end{array}$ & $\begin{array}{l}2^{\text {nd }} \\
\text { cut }\end{array}$ & $1^{\text {st }}$ cut & $\begin{array}{l}2^{\text {nd }} \\
\text { cut }\end{array}$ \\
\hline \multicolumn{7}{|c|}{$2003 / 2004$} \\
\hline Control & 43.92 & 53.67 & 16.11 & 29.22 & 3.66 & 3.27 \\
\hline NPK* & 57.00 & 54.92 & 22.61 & 33.42 & 4.31 & 3.35 \\
\hline $\operatorname{PM}\left(10 \mathrm{~m}^{3} / \mathrm{fad}\right)$ & 54.91 & 53.44 & 18.98 & 29.42 & 4.81 & 3.43 \\
\hline $\operatorname{PM}\left(20 \mathrm{~m}^{3} / \mathrm{fad}\right)$ & 61.61 & 62.60 & 19.90 & 35.61 & 4.68 & 3.50 \\
\hline Yeast at $5 \mathrm{~g} / \mathrm{L}$ & 51.89 & 53.93 & 17.80 & 32.03 & 4.07 & 3.34 \\
\hline PM $10 m^{3}+$ yeast at $5 \mathrm{~g} / \mathrm{L}$ & 59.55 & 65.06 & 19.61 & 35.94 & 5.37 & 4.24 \\
\hline PM 20m ${ }^{3}+$ yeast at $5 \mathrm{~g} / \mathrm{L}$ & 65.65 & 72.17 & 22.62 & 39.49 & 5.73 & 4.33 \\
\hline LSD at 0.05 & 2.19 & 1.05 & 2.76 & 1.99 & 0.04 & 0.11 \\
\hline \multicolumn{7}{|c|}{$2004 / 2005$} \\
\hline Control & 80.44 & 61.42 & 14.89 & 32.29 & 3.10 & 2.71 \\
\hline NPK* & 88.11 & 69.58 & 15.67 & 34.67 & 3.82 & 3.10 \\
\hline $\operatorname{PM}\left(10 \mathrm{~m}^{3} / \mathrm{fad}\right)$ & 82.33 & 62.94 & 16.89 & 36.91 & 4.07 & 3.45 \\
\hline $\operatorname{PM}\left(20 m^{3} /\right.$ fad $)$ & 86.89 & 71.12 & 15.44 & 39.78 & 3.84 & 3.54 \\
\hline Yeast at $5 \mathrm{~g} / \mathrm{L}$ & 84.34 & 67.92 & 15.33 & 33.99 & 3.64 & 2.92 \\
\hline PM $10 m^{3}+$ yeast at $5 \mathrm{~g} / \mathrm{L}$ & 84.56 & 76.58 & 17.45 & 37.70 & 3.57 & 3.47 \\
\hline PM $20 \mathrm{~m}^{3}+$ yeast at $5 \mathrm{~g} / \mathrm{L}$ & 87.11 & 78.22 & 17.67 & 39.90 & 4.23 & 3.22 \\
\hline LSD at 0.05 & 3.28 & 2.20 & 1.75 & 1.81 & 0.14 & 0.49 \\
\hline
\end{tabular}

$\mathrm{NPK}^{*}=300 \mathrm{~kg}$ ammonium sulphate $(20.6 \% \mathrm{~N})+200 \mathrm{~kg}$ calcium superphosphate $\left(15.5 \% \mathrm{P}_{2}\right.$ $\left.\mathrm{O}_{5}\right)+100 \mathrm{~kg}$ potassium sulphate $\left(48 \% \mathrm{~K}_{2} \mathrm{O}\right) /$ fad./ season. $\mathrm{PM}=$ Organic fertilizers ( Poultry manure).

Majorana hortensis, Naguib (2002) on Cymbopogon flexuosus ; Salman (2004) on Ocimum basilicum, they all showed that active dry yeast increased plant height.

In both seasons, data of both cuts reveal that the interaction between active dry yeast at $5 \mathrm{~g} / \mathrm{L}$ and organic fertilizer $(\mathrm{PM})$ used significantly increased plant height compared to the control. Increasing PM dose with active dry yeast at $5 \mathrm{~g} / \mathrm{L}$ gradually increased plant height. Using active dry yeast at the rate of $5 \mathrm{~g} / \mathrm{L}$ with $\mathrm{PM}$ at the rate of $20 \mathrm{~m}^{3} / \mathrm{fad}$ significantly increased plant height as compared to other treatments in both cuts.

\section{Number of branches/ plant:}

The results showed that NPK fertilization significantly increased number of branches / in both cuts of seasons compared to the control. Similar results were obtained by El-Ghadban (1998) on Mentha viridis and Origanum marjorana, who stated that NPK fertilization increased number of branches/ plant.

Regarding the effect of organic fertilizer, in the first season, data reveal that two organic fertilizer treatments used significantly increased number of branches/ 
plant in both two cuts compared to the control. Increasing fertilizer doses gradually increased number of branches/ plant. The best results were obtained due to PM at the rate of $20 \mathrm{~m}^{3} / \mathrm{fad}$. In the second season, in the first cut organic fertilizer at $10 \mathrm{~m}^{3} / \mathrm{fad}$ significantly increased number of branches/plant . In the second cut, PM at the rate of 10 and $20 \mathrm{~m}^{3} /$ fad significantly increased number of branches/ plant. These findings confirmed the previous works of Mohsen (2002) on Ocimum basilicum, who showed that organic fertilization increased the number of branches / plant .

Active dry yeast at $5 \mathrm{~g} / \mathrm{L}$ alone had no significant effect on the number of branches/plant in the first cut of the first season and both cuts of the second season, whereas in the second cut of the first season active dry yeast at $5 \mathrm{~g} / \mathrm{L}$ significantly increased number of branches/plant. These results agreed with the findings obtained by Salman (2004) on Ocimum basilicum.

In both seasons, data of both cuts reveal that the interaction between active dry yeast at $5 \mathrm{~g} / \mathrm{L}$ and organic fertilizer (PM) used significantly increased number of branches/ plant compared to the control . Increasing PM dose from 10 to $20 \mathrm{~m}^{3} / \mathrm{fad}$ with active dry yeast at $5 \mathrm{~g} / \mathrm{L}$ increased number of branches/ plant. The best results were obtained due to active dry yeast at the rate of $5 \mathrm{gm} / \mathrm{L}$ with $\mathrm{PM}$ at the rate of 20 $\mathrm{m}^{3} / \mathrm{fad}$.

\section{Leaf area:}

The results showed that NPK fertilizer significantly increased leaf area compared with control in the first cut in both seasons, whereas it had no significant effect on leaf area in the second cut. These results are in agreement with those obtained by Sakr (2001) on Mentha piperita and Mohsen (2002) on Ocimum basilicum.

The results showed that two doses of PM fertilizers had a significant effect in increasing leaf area in both cuts of the two seasons compared to control. Similar results were obtained by Sakr (2001) on Mentha piperita.

Active dry yeast alone significantly increased the leaf area compared to the control in the first cut of both seasons, while in the second cut it had no significant effect on leaf area .These results confirmed by El-Ghadban et. al., (2003 b) on Ricinus communis and Salman (2004) on Ocimum basilicum.

Interaction between active dry yeast at $5 \mathrm{~g} / \mathrm{L}$ with organic fertilizer $(\mathrm{PM})$ at 10 or $20 \mathrm{~m}^{3} /$ fad significantly increased leaf area in both seasons, in the two cuts compared to the control plants. In most cases, plants received active dry yeast at the rate of $5 \mathrm{~g} / \mathrm{L}$ with $\mathrm{PM}$ at the rate of $20 \mathrm{~m}^{3} / \mathrm{fad}$ had the widest leaf area.

\section{Leaves fresh and dry weights / plant:}

The results in Tables ( 2 and 3 ) showed that ,in the first and second cuts, NPK fertilizers significantly increased leaves fresh and dry weights /plant in both seasons compared with the control. Similar results were mentioned by Mohsen (2002) on Ocimum basilicum and Abd-El-Azim (2003) on Salvia officinalis 
Table (2 ): Effect of chemical, organic fertilizers (PM) and active dry yeast on leaves, stems and herb fresh weight(g/plant) of sage( Salvia officinalis, L. ) plants of 2003 / 2004 and 2004 / 2005 seasons.

\begin{tabular}{|c|c|c|c|c|c|c|}
\hline \multirow[t]{2}{*}{ Treatments } & \multicolumn{2}{|c|}{ Leaves F.W. } & \multicolumn{2}{|c|}{ Stems F.W. } & \multicolumn{2}{|c|}{ Herb F.W. } \\
\hline & $1^{\text {st }}$ cut & $2^{\text {nd }}$ cut & $1^{\text {st }}$ cut & $2^{\text {nd }}$ cut & $1^{\text {st }}$ cut & $2^{\text {nd }}$ cut \\
\hline \multicolumn{7}{|c|}{$2003 / 2004$} \\
\hline Control & 117.55 & 165.56 & 58.83 & 84.11 & 176.38 & 249.67 \\
\hline NPK* & 230.84 & 257.31 & 95.82 & 127.14 & 326.66 & 384.45 \\
\hline $\operatorname{PM}\left(10 \mathrm{~m}^{3} /\right.$ fad $)$ & 169.47 & 181.04 & 74.08 & 123.95 & 243.55 & 304.99 \\
\hline PM $\left(20 \mathrm{~m}^{3} /\right.$ fad $)$ & 217.58 & 299.58 & 93.25 & 130.42 & 310.83 & 430.00 \\
\hline Yeast at $5 \mathrm{~g} / \mathrm{L}$ & 150.88 & 164.60 & 79.54 & 96.40 & 230.42 & 261.00 \\
\hline PM $10 \mathrm{~m}^{3}+$ yeast at $5 \mathrm{~g} / \mathrm{L}$ & 197.77 & 329.35 & 93.06 & 136.76 & 290.83 & 466.11 \\
\hline PM $20 \mathrm{~m}^{3}+$ yeast at $5 \mathrm{~g} / \mathrm{L}$ & 234.23 & 388.18 & 115.35 & 169.04 & 349.58 & 557.22 \\
\hline LSD at 0.05 & 3.69 & 4.04 & 4.32 & 3.50 & 7.30 & 19.17 \\
\hline \multicolumn{7}{|c|}{$2004 / 2005$} \\
\hline Control & 137.31 & 391.52 & 64.36 & 233.34 & 201.67 & 624.86 \\
\hline NPK * & 206.18 & 515.97 & 80.98 & 252.08 & 287.16 & 768.05 \\
\hline $\operatorname{PM}\left(10 m^{3} /\right.$ fad $)$ & 170.70 & 456.68 & 81.53 & 188.32 & 252.22 & 645.00 \\
\hline $\operatorname{PM}\left(20 \mathrm{~m}^{3} /\right.$ fad $)$ & 173.78 & 480.39 & 86.22 & 203.50 & 260.00 & 683.89 \\
\hline Yeast at $5 \mathrm{~g} / \mathrm{L}$ & 154.15 & 433.70 & 64.74 & 196.69 & 218.89 & 630.39 \\
\hline PM $10 \mathrm{~m}^{3}+$ Yeast at $5 \mathrm{~g} / \mathrm{L}$ & 187.32 & 470.92 & 79.34 & 201.00 & 266.66 & 671.92 \\
\hline PM $20 \mathrm{~m}^{3}+$ Yeast at $5 \mathrm{~g} / \mathrm{L}$ & 193.76 & 493.40 & 88.79 & 217.10 & 282.55 & 710.50 \\
\hline LSD at 0.05 & 4.42 & 3.29 & 1.97 & 5.93 & 8.38 & 24.34 \\
\hline
\end{tabular}

$\mathrm{NPK}^{*}=300 \mathrm{~kg}$ ammonium sulphate $(20.6 \% \mathrm{~N})+200 \mathrm{~kg}$ calcium superphosphate $(15.5$ $\left.\% \mathrm{P}_{2} \mathrm{O}_{5}\right)+100 \mathrm{~kg}$ potassium sulphate $\left(48 \% \mathrm{~K}_{2} \mathrm{O}\right) /$ fed./ season .

$\mathrm{PM}=$ Organic fertilizers ( Poultry manure).

In both seasons, the data revealed that poultry manure at 10 and 20 $\mathrm{m}^{3} / \mathrm{fad} /$ season significantly increased leaves fresh and dry weights / plant compared with the control, but lower than the NPK treatment, in most cases. In both seasons, increasing PM dosage from 10 to $20 \mathrm{~m}^{3} / \mathrm{fad} /$ season gradually increased both fresh and dry weights of leaves in most cases. PM at $20 \mathrm{~m}^{3} / \mathrm{fad} . /$ season treatment was more effective than $10 \mathrm{~m}^{3} / \mathrm{fad} / \mathrm{season}$ in the two cuts in both seasons. These results confirmed by Mohsen (2002) on Ocimum basilicum who found that organic fertilization increased leaves fresh and dry weights.

Data revealed that active dry yeast alone at $5 \mathrm{~g} / \mathrm{L}$ significantly increased fresh and dry weights of leaves in the first cut of the first season, whereas it had no significant effect on both leaves fresh and dry weights in the second cut. In the second season, active dry yeast at $5 \mathrm{~g} / \mathrm{L}$ significantly increased fresh and dry weights of leaves in the two cuts compared with control. These results agreed with those obtained by Hussain (2002) on Majorana hortensis and Salman (2004) on Ocimum basilicum.

The interaction between active dry yeast and different rates of PM (10 and 20 $\mathrm{m}^{3} / \mathrm{fad} / \mathrm{season}$ ) significantly increased the leaves fresh and dry weights /plant 
Table (3 ): Effect of chemical, organic fertilizers and active dry yeast on leaves, stems and herb dry weight(gm /plant) of sage( Salvia officinalis, L. ) plants during of 2003 / 2004 and 2004 / 2005 seasons.

\begin{tabular}{|c|c|c|c|c|c|c|}
\hline \multirow[t]{2}{*}{ Treatments } & \multicolumn{2}{|c|}{ Leaves D.W. } & \multicolumn{2}{|c|}{ Stems D.W. } & \multicolumn{2}{|c|}{ Herb D.W. } \\
\hline & $1^{\text {st }}$ cut & $2^{\text {nd }}$ cut & $1^{\text {st }}$ cut & $2^{\text {nd }}$ cut & $1^{\text {st }}$ cut & $2^{\text {nd }}$ cut \\
\hline & \multicolumn{6}{|c|}{$2003 / 2004$} \\
\hline Control & 28.98 & 36.97 & 14.51 & 18.81 & 43.49 & 55.78 \\
\hline NPK * & 57.33 & 63.92 & 23.78 & 31.49 & 81.11 & 95.41 \\
\hline PM(10m $/$ fad $)$ & 39.65 & 47.41 & 17.42 & 32.39 & 57.07 & 79.80 \\
\hline $\operatorname{PM}\left(20 \mathrm{~m}^{3} / \mathrm{fad}\right)$ & 48.23 & 73.30 & 20.66 & 32.49 & 68.89 & 105.79 \\
\hline Yeast at $5 \mathrm{~g} / \mathrm{L}$ & 35.92 & 40.94 & 18.96 & 23.66 & 54.88 & 64.60 \\
\hline PM $10 \mathrm{~m}^{3}+$ yeast at $5 \mathrm{~g} / \mathrm{L}$ & 49.08 & 77.30 & 23.14 & 32.16 & 72.22 & 109.46 \\
\hline PM $20 \mathrm{~m}^{3}+$ yeast at $5 \mathrm{~g} / \mathrm{L}$ & 61.26 & 100.92 & 30.21 & 43.95 & 91.47 & 144.87 \\
\hline LSD at 0.05 & 4.05 & 7.53 & 3.08 & 7.46 & 3.69 & 10.25 \\
\hline \multicolumn{7}{|c|}{$2004 / 2005$} \\
\hline Control & 37.08 & 134.47 & 17.38 & 80.09 & 54.46 & 214.56 \\
\hline NPK * & 57.05 & 165.11 & 22.89 & 80.64 & 79.94 & 245.75 \\
\hline $\operatorname{PM}\left(10 \mathrm{~m}^{3} /\right.$ fad $)$ & 48.64 & 139.54 & 23.26 & 57.84 & 71.90 & 197.38 \\
\hline $\operatorname{PM}\left(20 \mathrm{~m}^{3} / \mathrm{fad}\right)$ & 48.36 & 163.36 & 24.01 & 69.19 & 72.37 & 232.55 \\
\hline Yeast at $5 \mathrm{~g} / \mathrm{L}$ & 46.97 & 143.56 & 19.82 & 65.27 & 66.79 & 208.83 \\
\hline PM $10 \mathrm{~m}^{3}+$ yeast at $5 \mathrm{~g} / \mathrm{L}$ & 51.47 & 137.32 & 21.82 & 58.60 & 73.29 & 195.92 \\
\hline PM $20 \mathrm{~m}^{3}+$ yeast at $5 \mathrm{~g} / \mathrm{L}$ & 51.69 & 161.83 & 21.69 & 74.65 & 73.38 & 236.48 \\
\hline LSD at 0.05 & 3.79 & 4.53 & 1.96 & 5.07 & 4.12 & 7.99 \\
\hline
\end{tabular}

$\mathrm{NPK}^{*}=300 \mathrm{~kg}$ ammonium sulphate $(20.6 \% \mathrm{~N})+200 \mathrm{~kg}$ calcium superphosphate $(15.5$ $\left.\% \mathrm{P}_{2} \mathrm{O}_{5}\right)+100 \mathrm{~kg}$ potassium sulphate $\left(48 \% \mathrm{~K}_{2} \mathrm{O}\right) /$ fed./ season .

$\mathrm{PM}=$ Organic fertilizers ( Poultry manure).

compared with the control in the first and second cuts of both seasons, except PM at $10 \mathrm{~m}^{3} / \mathrm{fad} /$ season combined with active dry yeast at $5 \mathrm{~g} / \mathrm{L}$ in the second cut of the second season which insignificantly increased leaves dry weight /plant.

\section{Stems fresh and dry weights/ plant:}

Data in Tables (2 and 3) showed that NPK fertilizers significantly increased stems fresh and dry weights /plant in the first and second seasons compared to the control plants in both cuts, except in the second cut of the second season which gave insignificantly heavier dry weight of stems compared with the untreated plants. Similar results were mentioned by Mohsen (2002) on Ocimum basilicum and Abd ElAzim (2003) on Salvia officinalis.

Organic manure (PM) at 10 and $20 \mathrm{~m}^{3} / \mathrm{fad} / \mathrm{season}$ significantly increased stems fresh and dry weights /plant compared to of the control plants in the first season in both cuts (except with plants received $10 \mathrm{~m}^{3} / \mathrm{fad} / \mathrm{season}$, giving insignificantly heavier dry weight of stems in the first cut ) and in the first cut of the second season 
only. Poultry manure at 10 and $20 \mathrm{~m}^{3} / \mathrm{fad} / \mathrm{season}$ significantly decreased fresh and dry weights of stems /plant in second cut of the second season compared with the control. Similar increase in stems fresh and dry weights as a result of organic fertilization was reported by El- Gendy et. al. (2001) on Ocimum basilicum.

Data revealed that active dry yeast alone at $5 \mathrm{~g} / \mathrm{L}$ significantly increased stems fresh weight /plant in the first season only. In the second season, active dry yeast at $5 \mathrm{gm} / \mathrm{L}$ had no effect on stem fresh weight in the first cut, while it significantly reduced the stems fresh weight compared with the control in the second cut. Also it can be noticed that, active dry yeast at $5 \mathrm{~g} / \mathrm{L}$ significantly increased stems dry weight in the first cut of both seasons. On contrast, spraying yeast at $5 \mathrm{~g} / \mathrm{L}$ insignificantly increased dry weight of stems in the second cut of the first season, whereas it decreased stems dry weight significantly in the second cut of the second season. The increase in both fresh and dry weights of stems as a result of spraying yeast is in agreement with the findings obtained by Naguib (2002) on Cymbopogon flexuosus and Salman (2004) on Ocimum basilicum.

The interaction between active dry yeast and different rates of PM (10 and 20 $\mathrm{m}^{3} / \mathrm{fad}$ ) significantly increased the stems fresh and dry weights /plant in the first season ( in both two cuts)and in the first cut of the second season, compared to the control. Increasing PM rate from $10 \mathrm{~m}^{3} /$ fad to $20 \mathrm{~m}^{3} / \mathrm{fed} /$ season alone or combined with active dry yeast at $5 \mathrm{~g} / \mathrm{L}$ gradually increased fresh and dry weights of stems/ plant. On the contrary, PM fertilizer at 10 and $20 \mathrm{~m}^{3} /$ fed combined with active dry yeast at $5 \mathrm{gm} / \mathrm{L}$ significantly decreased stem fresh and dry weights in the second cut of the second season compared with the control. In most cases, PM rate from at $20 \mathrm{~m}^{3}$ / fed/ season combined with active dry yeast at $5 \mathrm{gm} / \mathrm{L}$ significantly increased stem fresh and dry weights, compared to other treatments.

\section{Herb fresh and dry weights / plant:}

Data in Tables ( 2 and 3) showed that NPK dose significantly increased herb fresh and dry weights compared with the control plants in both cuts and second seasons. This effect confirmed the role of the nutrition in increasing the growth of plants such as fresh and dry matter. The favourable effect of NPK fertilization treatments on the vegetative growth characteristics (compared to the control) can be attributed to the important role played by $\mathrm{N}, \mathrm{P}$ and $\mathrm{K}$ in the physiological processes within the plant, which in turn affect the growth of the vegetative and root systems. Also, nitrogen is present in the structure of protein molecules, while phosphorus is an essential constituent of nucleic acids and phospholipids, and potassium is essential as an activator for enzymes involved in the synthesis of certain peptide bonds (Devlin, 1975). Similar results were mentioned by Sakr (2001) on Mentha piperita, and Mohsen (2002) on Ocimum basilicum, they indicated that NPK fertilization increased herbage fresh and dry weights per plant.

The data indicated that PM doses (10 and $\left.20 \mathrm{~m}^{3} / \mathrm{fad} / \mathrm{season}\right)$ significantly increased herb fresh and dry weights over the control plants (except PM fertilizer at $10 \mathrm{~m}^{3} / \mathrm{fad} /$ season in the second cut of the second season). Poultry manure at 20 $\mathrm{m}^{3} / \mathrm{fad} /$ season was more effective than $10 \mathrm{~m}^{3} / \mathrm{fad} / \mathrm{season}$ because of giving the higher 
values in both cuts in the first and second seasons. The favorable influence of organic manures (including poultry manure) on vegetative growth may be attributed to their effects on the soil, such as improving some of its chemical and physiochemical properties, improving water use efficiency (Wallace, 1994 a), preventing salt injury to plants that sometimes results from concentration of chemical fertilizers through the buffering properties of organic matter (Wallace, $1994 \mathrm{~b}$ ), and providing the soil with essential macro and micronutrients (Awad et al., 1993). Also, the addition of manures to the soil increases its cation exchange capacity (CEC) due to the ability of the negatively charged organic matter particles to attract and hold the positively charged cation in the soil, and to provide the plan roots with these cation. Moreover, the addition of manures to the sandy soil increases the soil's water-holding capacity which, in turn, allows higher absorption of water and nutrients from the soil, and enables photosynthesis to occur efficiently within the plant leaves ( Hartmann et al., 1981). These results agreed with those obtained by El-Gendy et. al., (2001) on Ocimum basilicum; Sakr (2001) on Mentha piperita and Mohsen (2002) on Ocimum basilicum .

The data revealed that active dry yeast alone at $5 \mathrm{~g} / \mathrm{L}$ had a significant effect on increasing herb fresh and dry weights / plant in the first cut of both seasons. On the other hand, in the second cut of both seasons active dry yeast had no significant effect on herbage fresh and dry weights compared to the control. These results agreed with the findings obtained by Hussain (2002) on Majorana hortensis and Salman (2004) on Ocimum basilicum.

The interaction between active dry yeast at $5 \mathrm{~g} / \mathrm{L}$ and PM fertilizer at 10 and $20 \mathrm{~m}^{3} / \mathrm{fad} / \mathrm{season}$ significantly increased the herb fresh and dry weights over the control in both cuts of the two seasons, except PM at $10 \mathrm{~m}^{3} /$ fad combined with yeast at $5 \mathrm{~g} / \mathrm{L}$ which significantly decreased herb dry weight in the second cut of the second season. Poultry manure at $20 \mathrm{~m}^{3} / \mathrm{fad}$ combined with yeast at $5 \mathrm{~g} / \mathrm{L}$ significantly increased herb fresh and dry weights as compared to other treatments in both cuts, in the first season.

\section{Recommendation:}

From the above mentioned results, it can be recommended that, sage (Salvia officinalis, L.) plants should be fertilized with poultry manure at $20 \mathrm{~m}^{3} / \mathrm{fad} /$ season combined with active dry yeast at $5 \mathrm{~g} / \mathrm{L}$ for high vegetative growth and yield.

\section{REFERENCES}

Abd El-Azim, W. M. (2003): Production of Salvia officinalis, L. plant under Sinai conditions. Ph. D. Thesis, Fac. Agric., Cairo Univ.

Ahmed, F. F. ; A. M. Akl ;F. M. El- Morsy and M. A. Ragab (1997) : The beneficial effects of biofertilizers on red roomy grapevines (Vitis vinifera, L.). Annals of Agric. Sci., Moshtohor.,35 (1) : 489 - 495. 
Awad, F.; K. W. Khalil and M. A. Maksoud (1993): Comparative effects of some organic manures and bentonite as soil amendments. Agrochimica., 37(6): 369387. (Soils and Fertilizers, 58: 2948).

Blumenthal , M.; A. Goldberg ; J. Brinckmann ; S. Foster and V. E. Tyler(2000): Herbal Medicine. Integrative Medicine Communications, USA., pp. 330 -334.

Devlin R.M. (1975): Plant Physiology. $3^{\text {rd }}$ Ed., Affiliated East-West Press Pvt. Ltd., New Delhi.

Eid, N. M. (1977): Some studies of the utilization of yeast in human nutrition. Ph.D. Thesis, Fac. Agric., Cairo Univ., Egypt.

El-Gendy, S. A.; A. M. Hosni; S. S. Ahmed and R. M. Sabri (2001): Sweet basil (Ocimum basilicum, L. ) productivity under different organic fertilization and inter plant spacing levels in a newly reclaimed land in Egypt. Annals of Agricultural Science, Cairo., 46(1): 319-338.

El- Ghadban, E. A. E. (1998): Effect of some organic and inorganic fertilizers on growth, oil yield and chemical composition of spearmint and marjoram plants. Ph.D. Thesis, Fac. Agric., Cairo Univ., Egypt.

El- Ghadban, E. A. E..; A. M. Ghallab and A. F. Abdel-Wahab ( 2003a): Effect of organic fertilizer and Biofertilization on growth, yield and chemical composition of marjoram plants under newly reclaimed soil conditions. $J$. Agric. Sci. Mansoura Univ., 28 (9): 6957 - 6973.

El- Ghadban, E. A. E.; Shadia K. Ahmed and M. I. Eid (2003 b) : Effect of foliar spraying with active dry yeast and complete fertilizer (Sengral) on growth, yield and fixed oil of Ricinus communis L. Egypt. Pharm. J., 1 : $55-66$.

Hartmann, H.T.; W.J. Flocker and A.M. Kofranek (1981): Plant Science "Growth, Development and Utilization of Cultivated Plants". Prentice-Hall, Inc., New York, U.S.A., pp.178-179.

Hussain, M. A. M. (2002): Effect of some agricultural treatments on growth and chemical composition of Majorana hortensis, Moench, plants. M. Sc. Thesis, Fac. Agric., Minia Univ.

Jackson, M. L. (1973): Soil Chemical Analysis. Printice - hall of India private. New Delhi , pp. 144-197.

Jacoub, Rola W. (1999): Effect of some organic and nonorganic fertilizers on growth, oil yield and chemical composition of Ocimum basilicum, L. and Thymus vulgaris, L. plants. Ph.D. Thesis, Fac. Agric., Cairo Univ., Egypt.

Lawless , J. ( 1992 ): The Encyclopaedia of Essential Oils. Element Books Limited, Longmead, Shaftesbury, Dorset, London, USA, Element, Inc.42 Broadway, Rockport, MA 01966.,164-165.

Mohsen, Maie M. A. (2002): Sweet basil herb and oil production as affected by chemical and organic fertilization. M. Sc. Thesis, Fac. Agric., Cairo Univ., Egypt.

Moor, T. C. (1979): Biochemistry and Physiology of Plant Hormones. Springer Verlag, New York, U.S.A. 
Naguib, Nabila Y. (2002): Yield and quality of lemongrass plants (Cymbopogon flexuosus, Stapf) as influenced by farm yard manure and foliar application of bread yeast. Annals Agric. Sci. Ain Shams Univ., Cairo, 47(3): 859-873.

Natio, K. ; S. Nagamo ; K. Furye and H. Suzki (1981): Effect of benzyladenine on RNA and protein-synthesis in intact bean leaves at various stages of aging. Physiology of Plant, 52 : 343 - 348.

Sakr, Weam. R. A. (2001): Effect of some organic and inorganic fertilizers on Mentha piperita. M. Sc. Thesis, Fac. Agric., Cairo Univ., Egypt.

Salman, A.S. (2004): Effect of biofertilization on Ocimum basilicum L. plant. M. Sc. Thesis, Fac. Agric., Cairo Univ., Egypt.

Snedecor, G. W. and W. G. Cochran ( 1980 ): Statistical Methods. $6^{\text {th }}$ Ed., The Iowa State Univ., Press, Iowa , U.S.A.

Wallace, A. (1994 a): Soil organic matter is essential to solving soil and environmental problems. Commun. Soil Sci. Plant Anal., 25 (1-2): 15- 28. (Soils and Fertilizers, $58: 4876$ ).

Wallace, A. (1994 b): Ten reasons why organic growers do not use synthetically compounded fertilizers. Commun. Soil Sci. Plant Anal., 25 (1-2): 125- 128. (Soils and Fertilizers, $58: 4264$ ). 


\title{
تأثثير التسميد الكيماوي والعضوي والرش بالخميرة علي نباتات المريمية أـ التأثير علي النمو والمحصول.
}

\author{
أحمد سلامه الليثي* ـ محمد موسي محمد حسين*ـ الموافي عبده الموافي الغضبان*** ـ إسراء

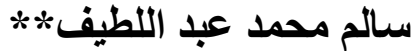

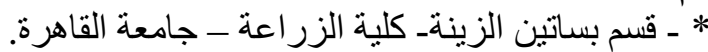

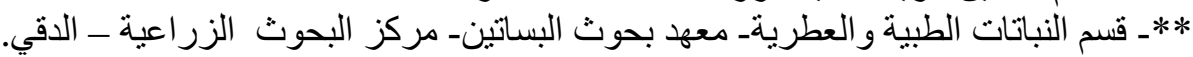

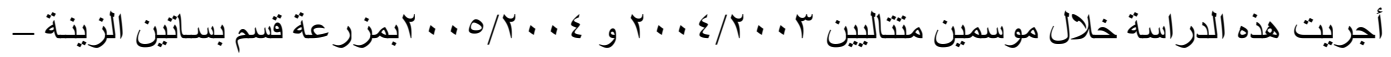

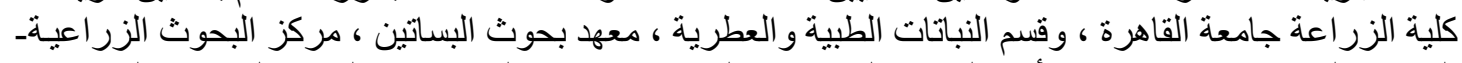

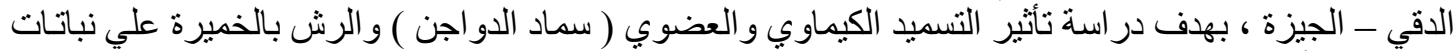
المريمية. وأوضحت النتائج مايلي: النئي

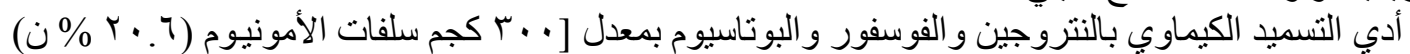

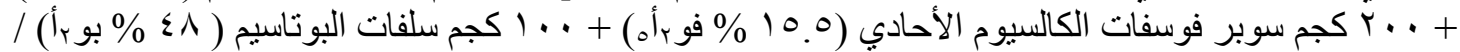

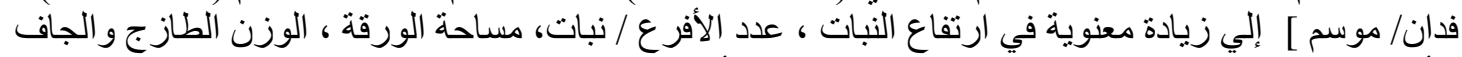
للأور اق و السيقان و العشب مقارنة بالكنترول في في معظم الأحيان.

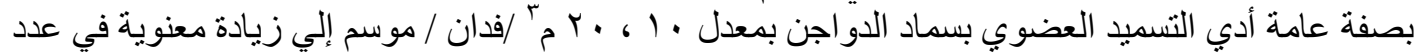

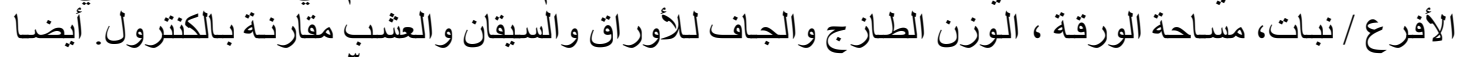

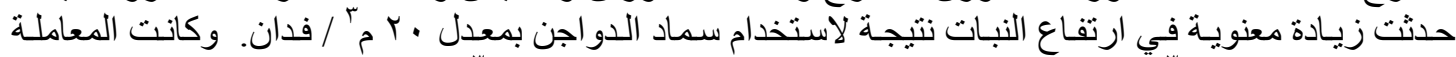

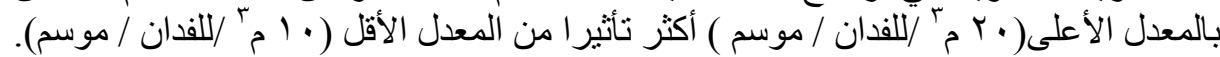

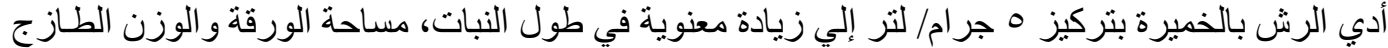

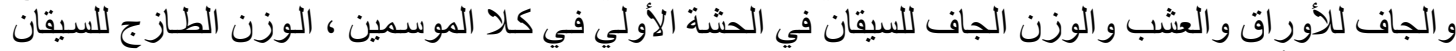

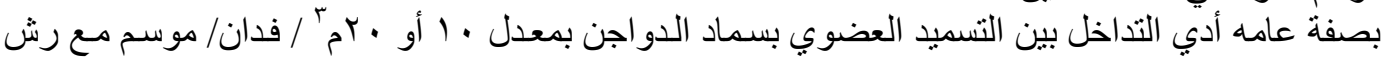

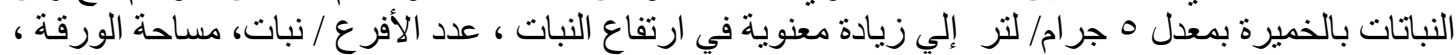

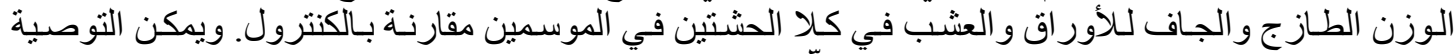

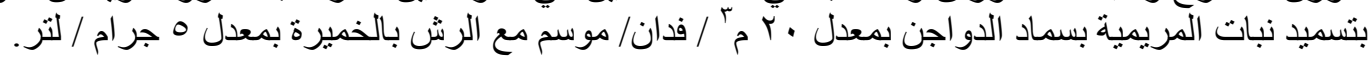

